\title{
Metode Air untuk Meningkatkan Keterampilan Menulis Teks Eksposisi Siswa Kelas X
}

\author{
Lastri Elfrida Simanjuntak ${ }^{1^{*}}$ \\ ${ }^{1}$ Jurusan Pendidikan Bahasa dan Sastra Indonesia, Universitas Pendidikan Ganesha, Singaraja, Indonesia
}

\section{A R T I C L E I N F O}

Article history:

Received July 16, 2021

Revised July 19, 2021

Accepted October 20, 2021

Available online November 25, 2021

Kata Kunci:

Metode AIR, Menulis Teks Eksposisi

Keywords:

AIR Method, Writing Exposition Text

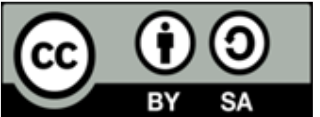

This is an open access article under the CC BY-SA license.

Copyright (@) 2021 by Author. Published by Universitas Pendidikan Ganesha.

\begin{abstract}
A B S T R A K
Kurangnya pemahaman tentang teori teks eksposisi dan kurangnya praktik langsung menulis teks eksposisi pada siswa kelas X. Hal tersebut membuat siswa cenderung pasif dan merasa bosan dengan proses pembelajaran menulis. Penelitian ini bertujuan untuk menganalisis metode air untuk meningkatkan keterampilan menulis teks eksposisi siswa kelas X. Penelitian ini adalah penelitian tindakan kelas yang dilaksanakan dalam dua siklus, yang terdiri dari rencana tindakan, pelaksanaan tindakan, observasi atau evaluasi dan refleksi. Subjek penelitian ini adalah siswa kelas $\mathrm{X}$ berjumlah 30 orang dengan rincian 10 orang putra dan 20 orang putri. Data dianalisis menggunakan statistik deskriptif. Hasil analisis menunjukkan bahwa rata-rata nilai keterampilan menulis teks eksposisi siklus I yaitu sebesar 78,9 dan rata-rata nilai keterampilan menulis teks eksposisi pada siklus II yaitu sebesar 90,9. Dapat disimpulkan bahwa hasil belajar keterampilan menulis teks eksposisi pada siklus I ke siklus II mengalami peningkatan sebesar 28,0. Maka, hasil belajar keterampilan menulis teks eksposisi meningkat melalui penerapan metode $A I R$. Implikasi penelitian ini diharapkan dapat membantu guru dalam meningkatkan kemampuan keterampikan menulis teks eksposisi.
\end{abstract}

\section{A B S T R A C T}

Lack of understanding of the theory of exposition texts and lack of direct practice of writing exposition texts. It makes students tend to be passive and feel bored with the writing process. This study aims to analyze the water method to improve the writing skills of the tenth graders of exposition text. This research is classroom action research that is carried out in two cycles: an action plan, action implementation, observation or evaluation, and reflection. The subjects of this study were 30 students of class $X$, with details of 10 sons and 20 daughters. Data were analyzed using descriptive statistics. The results of the data analysis showed that the average value of the exposition text writing skill in the first cycle was 78.9, and the average exposition text writing skill score in the second cycle was 90.9. From the learning outcomes data, it can be said that the learning outcomes of critical response text writing skills in cycle I to cycle II have increased by 28.0. Thus, the learning outcomes of expository text writing skills are increased by applying the AIR method. The implications of this research are expected to assist teachers in improving the skills of writing exposition texts.

\section{PENDAHULUAN}

Menulis merupakan salah satu aspek keterampilan berbahasa yang harus dikuasai oleh siswa (Andayani \& -, 2018; Natalita et al., 2019). Keterampilan menulis digunakan oleh siswa untuk berkomunikasi secara tidak langsung (Aprelia Dea Ayu, Sunan Baedowi, 2019; Naitili et al., 2019). Komunikasi tidak langsung adalah komunikasi tanpa tatap muka yang dilakukan melalui media perantara yaitu bahasa (Hodiyanto, 2017; Puspitasari, 2012). Menulis merupakan suatu keterampilan berbahasa yang dipergunakan untuk berkomunikasi secara tidak langsung, tidak tatap muka dengan orang lain (Putri et al., 2019; Widyaningrum, 2019). Keterampilan menulis yang tidak diimbangi dengan praktik menjadi salah satu faktor kurang terampilnya siswa dalam menulis. Siswa pada sekolah menengah atas seharusnya sudah lebih dapat untuk mengekspresikan gagasan, pikiran, dan perasaannya secara tertulis. Pembelajaran menulis lebih banyak disajikan dalam bentuk teori bukan praktik (Natalita et al., 2019). Hal ini menyebabkan esensi pembelajaran menulis yang arahnya pada keterampilan menulis bergeser pada 
pengetahuan tentang menulis.

Namun, kebiasaan ini berdampak pada siswa yaitu kurangnya kebiasaan menulis siswa sehingga mereka sulit menuangkan ide mereka dalam bentuk tulisan. Kegiatan menulis belum sepenuhnya terlaksana (S et al., 2016; Yarmi, 2017). Menyusun suatu gagasan, pendapat, dan pengalaman menjadi suatu rangkaian berbahasa tulis yang teratur, sistematis, dan logis bukan merupakan pekerjaan mudah, melainkan pekerjaan yang memerlukan latihan terus-menerus (Gusrita, 2021). Siswa kelas X di SMA sering mengalami kesulitan dalam memaparkan, menjelaskan, menyampaikan informasi, mengajarkan, dan menerangkan sesuatu yang akan dituangkan dalam tulisan teks eksposisi. Siswa menuturkan bahwa lemahnya siswa menulis karena selama ini mereka hanya mengetahui teori tentang menulis dan kurangnya pemahaman tentang teori teks eksposisi dan kurangnya praktek langsung menulis teks eksposisi. Hal tersebut membuat siswa cenderung pasif dan merasa bosan dengan proses pembelajaran menulis. siswa kesulitan memahami materi tentang teks eksposisi, keterbatasan pengetahuan, ide, dan gagasan dalam menyusun teks eksposisi, siswa kurang memahami struktur dan ciri kebahasaan teks eksposisi, siswa kesulitan dalam menjabarkan kalimat utama menjadi kalimat penjelas, dan kurangnya penguasaan kata baku. Terakhir, siswa kurang termotivasi menghasilkan teks eksposisi karena merasa tidak mendapat manfaat nyata dari materi ini.

Permasalahan yang ada dari segi guru yaitu guru masih menggunakan pendekatan tradisional dalam pembelajaran menulis. Kurangnya kemampuan guru dalam pengelolaan kelas. Proses pembelajaran yang dilakukan selama ini hanya berkisar penyampaian materi dengan ceramah dan mencatat. Di samping itu, guru belum pernah mengikuti pelatihan mengenai metode untuk meningkatkan kemampuan siswa dalam menulis. Tentunya hal ini berpengaruh terhadap kemampuan menulis siswa. Hasil wawancara yang dilakukan saat pembelajaran Bahasa Indonesia berlangsung sejalan dengan pernyataan para guru yang mengajar di kelas X MIPA 7 SMA Negeri 1 Singaraja. Menurut keterangan guru bahasa Indonesia di SMA Negeri 1 Singaraja, sebagian besar siswa mengalami kesulitan dalam menulis teks eksposisi. Siswa antara mengalami kesulitan memunculkan dan menuangkan ide dalam tulisan, bahasa yang digunakan baik, serta faktor minat dan antusiasme siswa dalam mengikuti pembelajaran menulis teks ekposisi sangat kurang. Kadang-kadang siswa merasa bosan jika diminta untuk menulis dan membutuhkan waktu yang lama dalam pengerjaannya. Padahal di setiap pembelajaran, guru meminta siswa menulis teks yang akan diajarkan. Tuntuan KKM dalam pembelajaran hahasa Indonesia yang harusnya dicapai minimal 83 hanya diperoleh siswa sejumlah 60 yang artinya belum lulus. Selain itu, kegiatan pembelajaran yang berlangsung di sekolah yang biasanya kegiatan menulis yang dianggap kurang maksimal karena kurangnya pengetahuan

Solusi yang dapat dilakukan untuk mengatasi permasalahan tersebut yaitu dengan melalui melalui metode $A I R$. Metode AIR dapat merangsang daya kembang dan pola pikir anak di mana anak mendapat suatu pemahaman berupa informasi terkait suatu topik yang sedang dibahas melalui mendengarkan, mengingat, dan mengatakan secara ulang kembali apa yang ia telah dengarkan (Astuti et al., 2018; Elinawati et al., 2018). Hal itu akan membantunya untuk menuliskan kembali informasi tersebut dengan bahasanya sendiri. Metode AIR, yaitu singkatan dari Auditition Intellectually Repetition. Metode AIR digunakan guru sebagai strategi untuk membuat siswa menjadi lebih aktif, lebih semangat, lebih inovatif, dan mempermudah siswa dalam mengikuti pelajaran (Astuti et al., 2018; Bonatua et al., 2021). Model auditory, intellectual, repetition merupakan model yang melatih siswa untuk lebih berperan aktif, mengembangkan pola pikir dengan cara mendengarkan atau menyimak, daya tangkap dalam proses berpikir, dan berinteraksi saat proses pembelajaran untuk siswa mampu meningkatkan kemampuan berpikirnya (Wahyuni et al., 2018). Setelah itu, siswa membuat atau menuliskan kembali apa yang telah didengar atau disimak yang menentukan siswa dapat mengusai pembelajaran yang telah diberikan atau pengulasan kembali (Agustiana et al., 2018; Dewi \& Kristiantari, 2020; Elinawati et al., 2018). Dengan model pembelajaran, ini siswa akan lebih mudah dalam menyusun teks eksposisi. Siswa dapat menulis berdasarkan informasi atau pengetahuan yang dipaparkan oleh temannya dan dijelaskan kembali secara singkat oleh guru kelas (Elinawati et al., 2018; Fitriana \& Ismah, 2016).

Beberapa temuan penelitian sebelumnya menyatakan model pembelajaran auditory intellectually repetition dapat meningkatkan hasil belajar matematika siswa (Elinawati et al., 2018; Fitriana \& Ismah, 2016). Model Pmbelajaran auditory intellectually repetition dapat digunakan untuk meningkatkan kemampuan berpikir kritis siswa (Astuti et al., 2018). Pemahaman konsep siswa dan kompetensi terkait dengan materi dapat menggunakan metode auditory intellectually repetition (Dewi \& Kristiantari, 2020; Sarniah et al., 2019). Namun, penerapan metode AIR belum perna diterapkan dalam pembelajaran keterampilan menulis teks eksposisi. Kegiatan penelitian ini yaitu menulis teks eksposisi menggunakan metode yang dianggap tepat sesuai tuntutan kompetensi dasar yaitu metode AIR untuk membantu siswa dalam keterampilan menulis teks eksposisi. Jenis teks yang dipelajari siswa dalam pembelajaran Bahasa Indonesia sangat beragam dan sesuai dengan tingkatannya. Untuk tingkat SMA sederajat, ada sekitar tiga 
puluh teks yang dipelajari siswa (Kemendikbud, 2016). Oleh sebab itu, siswa SMA kelas X harus mampu menulis teks eksposisi dengan baik sesuai dengan ketentuan teks tersebut baik dari segi struktur dan kaidah kebahasaan teks eksposisi. Tujuan penelitian ini yaitu untuk menganalisis metode air untuk meningkatkan keterampilan menulis teks eksposisi siswa kelas X.

\section{METODE}

Penelitian ini mengikuti tahap-tahap penelitian tindakan kelas yang masing-masing siklus terdiri atas empat tahap yaitu perencanaan tindakan, pelaksanaan tindakan, observasi atau evaluasi,) refleksi. Tempat dan waktu dilaksanakannya penelitian. Penelitian ini dilaksanakan di SMA Negeri 1 Singaraja. Subjek dalam penelitian ini adalah siswa Kelas X MIPA 7 SMA Negeri 1 Singaraja. Objek dalam penelitian ini adalah langkah-langkah penerapan metode $A I R$ untuk meningkatkan keterampilan menulis teks tanggapan kritis siswa kelas X MIPA 7 SMA Negeri 1 Singaraja dan respons siswa X MIPA 7 SMA Negeri 1 Singaraja terhadap penerapan metode $A I R$ untuk meningkatkan keterampilan menulis teks eksposisi. Data yang diperlukan untuk menjawab permasalahan yang ingin dipecahkan ialah data mengenai kemampuan menulis teks eksposisi, data mengenai langkah-langkah pembelajaran, data mengenai respons siswa terhadap pembelajaran yang telah dilakukan. Untuk mengumpulkan data-data tersebut, peneliti menggunakan empat metode, yaitu metode observasi, metode tes, dan metode angket. Analisis data yang digunakan dalam penelitian ini adalah analisis deskriptif kualitatif dan deskriptif kuantitatif. Ada tiga data yang harus dianalisis dalam penelitian ini. Data mengenai kemampuan menulis teks eksposisi yang diperoleh melalui metode tes dianalisis secara deskriptif kuantitatif, data mengenai langkah-langkah pembelajaran yang diperoleh melalui metode observasi dianalisis secara deskriptif kualitatif, data mengenai respons siswa yang diperoleh melalui metode angket dianalisis secara kuantitatif dan kualitatif. Kriteria keberhasilan hasil belajar kemampuan menulis teks tanggapan kritis ditunjukkan dengan adanya keberhasilan pemerolehan skor rata-rata kelas pada kategori baik atau 85\% dari jumlah keseluruhan siswa memeroleh nilai kategori baik. Kedua, kriteria respons siswa ditunjukkan oleh perolehan apabila masuk kriteria jumlah keseluruhan siswa merespons positif atau senang dengan tindakan pembelajaran.

\section{HASIL DAN PEMBAHASAN}

\section{Hasil}

Penelitian ini diawali dengan melakukan observasi awal yang dilakukan oleh peneliti pada siswa kelas X MIPA 7 SMA Negeri 1 Singaraja bersamaan saat melaksanakan pengajaran bahasa Indonesia berkaitan dengan PPL-PPG di sekolah tersebut. Peserta didik kelas X MIPA 7 SMA Negeri 1 Singaraja mengalami masalah dalam hasil belajar keterampilan menulis teks eksposisi. Hal ini dapat dilihat dari nilai menulis teks eksposisi yang dicapai oleh peserta didik belum mencapai standar yang ditetapkan. Persentase ketuntasan hasil belajar peserta didik dilihat dari nilai hariah semester ganjil tahun ajaran 2017/2018 untuk X MIPA 7 SMA Negeri 1 Singaraja dari 30 peserta didik 18 orang belum tuntas. Ketidaktuntasan tersebut menunjukkan bahwa hasil belajar keterampilan menulis teks eksposisi peserta didik masih belum memenuhi apa yang diharapkan. Dari hasil penelitian pada siklus I menunjukkan bahwa 12 orang sudah tuntas dengan rata-rata nilai secara klasikal 40. Dapat disimpulkan, penelitian pada siklus I belum berhasil karena dari 18 siswa masih ada yang belum memenuhi KKM yaitu 83 sesuai yang berlaku di SMA Negeri 1 Singaraja. Selanjutnya dilakukan refleksi dengan memperhatikan data hasil belajar peserta didik pada siklus I, permasalahan-permasalahan yang dihadapi adalah berikut. 1) Siswa tampak kesulitan mengembangkan ide pokok paragraf. 2) Siswa belum sepenuhnya mengikuti kerangka tulisan saat menulis teks sehingga tulisannya tidak terstruktur. 3) Siswa kesulitan dalam merangkai kalimat efektif dalam sebuah paragraf. 4) Siswa kesulitan dalam menentukan pilihan kata. 5) Siswa kesulitan dalam menggunakan ejaan yang tepat. Penggunaan tanda baca seperti koma dan tanda titik masih banyak kesalahan.

Berpedoman pada beberapa penyebab kesulitan siswa di atas, siklus II akan diawali dengan membahas hal ini. Tujuannya agar siswa memperoleh konsep yang benar tentang kesalahan yang telah dilakukannya pada siklus sebelumnya. Untuk itu, dilakukan beberapa perbaikan pada siklus II. Perbaikan yang dilakukan adalah: 1) Siswa diarahkan untuk mencermati dan mengkaji ulang tentang tema yang diperoleh untuk mengumpulkan informasi. 2) Siswa diarahkan untuk agar mampu menyusun kalimat penjelas berdasarkan kalimat utama yang disediakan menjadi sebuah paragraf. 4) Siswa dibimbing untuk memperbaiki kalimat yang tidak efektif menjadi kalimat efektif, dan 5) Siswa dibimbing menggunakan pilihan kata dalam kalimat. Berdasarkan uraian di atas, maka penelitian ini dilanjutkan ke siklus II. Hasil dari refleksi siklus I ini digunakan sebagai referensi dalam melaksanakan penelitian pada siklus II dengan tujuan untuk dapat meningkatkan hasil belajar yang lebih baik. Dari hasil penelitian pada siklus II dengan pembelajaran menulis teks tanggapan kritis menunjukan bahwa 27 orang sudah tuntas dengan rata-rata 
nilai secara klasikal 90. Berdasarkan data hasil belajar tersebut dapat dinyatakan bahwa keterampilan menulis teks eksposisi siswa kelas X SMA Negeri 1 Singaraja dari siklus I ke siklus II mengalami peningkatan. Penelitian pada siklus II sudah berhasil karena hasil pembelajaran menulis teks eksposisi sudah memenuhi bahkan melewati standar KKM yaitu 83 sesuai yang berlaku di SMA Negeri 1 Singaraja. Peningkatan hasil belajar pada siklus II tersebut dikarenakan penerapan metode AIR dan melakukan perbaikan berdasarkan kendala-kendala yang dialami pada siklus I.

\section{Pembahasan}

Penerapan metode AIR dapat meningkatkan keterampilan menulis teks eksposisi siswa kelas X. Peningkatan keterampilan menulis teks eksposisi siswa dilihat dari siswa yang mendapat model pembelajaran AIR lebih baik dibandingkan keterampilan menulis teks eksposisi siswa yang mendapat model pembelajaran konvensional. Pembelajaran AIR menganggap bahwa suatu pembelajaran akan efektif jika memperhatikan tiga hal, yaitu Auditory (mendengar), Intellectully (berpikir), dan Repetition (pengulangan) (Linuwih \& Sukwati, 2014). Peningkatan hasil belajar dalam penelitian ini tidak terlepas dari kelebihan-kelebihan penerapan metode $A I R$ yang menjadikan setiap peserta didik menjadi lebih siap dalam mengikuti pembelajaran khususnya dalam pembelajaran bahasa Indonesia, serta dikarenakan penerapan metode pembelajaran ini mengarahkan agar peserta didik pandai-pandai menganalisis masalah, mengumpulkan data atau fakta yang mendukung opininya, dan membuat kesimpulan sendiri dibimbing oleh guru (Agustiana et al., 2018; Elinawati et al., 2018). Oleh karena itu, semua peserta didik dituntut untuk berpikir kritis dalam memahami topik yang akan ditulis menjadi sebuah teks ekposisi sesuai struktur dan ciri kebahasaannya. Hasil belajar peserta didik dapat meningkat juga disebabkan karena dalam proses pembelajaran peserta didik telah mampu belajar dan beraktivitas sendiri untuk memperoleh pengalaman, pengetahuan, pemahaman dan tingkah laku lainnya, mampu bekerjasama dengan temannya, mengembangkan keterampilan yang dimiliki serta sudah mulai sangat aktif dan antusias selama proses pembelajaran sehingga dapat memahami materi pelajaran dengan sangat baik.

Metode AIR dapat meningkatkan keterampilan menulis teks eksposisi siswa kelas X .Model pembelajaran Auditory, Intelectually, Reptition (AIR) berasal dari kata Auditory yang bermakna bahwa belajar haruslah dengan melalui proses yang dimulai mendengarkan, menyimak, berbicara, persentasi, argumentasi mengemukakan pendapat dan menanggapi (Agustiana et al., 2018; Linuwih \& Sukwati, 2014). Intelectually bermakna bahwa belajar haruslah menggunakan kemampuan berpikir (Agustiana et al., 2018). Terakhir Repetition, yang bermakna pengulangan dalam konteks pembelajaran. Pemilihan model pembelajaran AIR ini juga karena merupakan salah satu model yang efektif untuk meningkatkan hasil belajar peserta didik (Astuti et al., 2018; Dewi \& Kristiantari, 2020; Sarniah et al., 2019). Temuan ini diperkuat dengan temuan sebelumnya yang menyatakan model pembelajaran auditory intellectually repetition dapat meningkatkan hasil belajar matematika siswa (Elinawati et al., 2018; Fitriana \& Ismah, 2016). Model pembelajaran auditory intellectually repetition dapat digunakan untuk meningkatkan kemampuan berpikir kritis siswa (Astuti et al., 2018). Pemahaman konsep siswa dan kompetensi terkait dengan materi dapat menggunakan metode auditory intellectually repetition (Dewi \& Kristiantari, 2020; Sarniah et al., 2019). Dari pembahasan tersebut, metode auditory intellectually repetition dapat meningkatkan kemampuan menulis teks eksposisi. Metode AIR juga dapat diterapkan guru pada pembelajaran lainnya untuk meningkatkan kemampuan keterampilan lainnya. Implikasi dari penelitian ini diharapkan dapat membantu guru dalam meningkatkan kemampuan keterampikan menulis teks eksposisi.

\section{SIMPULAN}

Keterampilan menulis teks eksposisi siswa meningkat dengan penerapan metode AIR. Keterampilan menulis teks eksposisi menggunakan metode yang dianggap tepat sesuai tuntutan kompetensi dasar yaitu metode AIR untuk membantu siswa dalam keterampilan menulis teks eksposisi. Metode AIR dapat merangsang daya kembang dan pola pikir siswa. Siswa mendapat suatu pemahaman berupa informasi terkait suatu topik yang sedang dibahas melalui mendengarkan, mengingat, dan mengatakan secara berulang sesuatu yang ia telah dengarkan. Hal itu dapat membantunya untuk menuliskan kembali informasi tersebut dengan bahasanya sendiri.

\section{DAFTAR RUJUKAN}

Agustiana, E., Putra, F. G., \& Farida, F. (2018). Penerapan Model Pembelajaran Auditory, Intellectually, Repetition (AIR) dengan Pendekatan Lesson Study terhadap Kemampuan Pemecahan Masalah Matematis Peserta Didik. Desimal: Jurnal Matematika, 1(1), 1-6. https://doi.org/10.24042/djm.v1i1.1905. 
Andayani, T., \& -, A. (2018). Improving Students' Ability in Writing Narrative Text by Using Picture Series for the Eight Grade Students of Junior High School. JOALL (Journal of Applied Linguistics \& Literature), 1(2), 1-10. https://doi.org/10.33369/joall.v1i2.4174.

Aprelia Dea Ayu, Sunan Baedowi, M. (2019). Pengaruh Pendekatan Kontekstual dalam Meningkatkan Keterampilan Menulis Narasi. Mimbar Ilmu, 7(3), 237-244. https://doi.org/10.23887/jjpgsd.v7i3.19400.

Astuti, R., Yetri, Y., \& Anggraini, W. (2018). Pengaruh Model Pembelajaran Auditory Intellectually Repetition (AIR) terhadap Kemampuan Berpikir Kritis Siswa pada Materi Kemagnetan Kelas IX SMP N 1 Penengahan Lampung Selatan. Inodesian Journal Of Science and Mathematics Education, 1(2), 1-12. https://doi.org/10.24042/ijsme.v1i2.2765.

Bonatua, D. S., Mulyono, D., \& Febriandi, R. (2021). Penerapan Model Pembelajaran AIR (Auditory, Intellectualy, Repetition) menggunakan Media Gambar pada Pembelajaran Tematik Sekolah Dasar. Jurnal Basicedu, 5(5), 3850-3857. https://doi.org/10.31004/basicedu.v5i5.1462.

Dewi, A. D. Y. R., \& Kristiantari, M. R. (2020). Pengaruh Model Pembelajaran Auditory Intellectually Repetition Berbantuan Multimedia terhadap Kompetensi Pengetahuan IPA. Mimbar Ilmu, 25(1), 75-86. https://doi.org/10.23887/mi.v25i1.24479.

Elinawati, W., Duda, H. J., \& Julung, H. (2018). Penerapan Model Pembelajaran Auditory, Intellectually, Repetition (Air) terhadap Hasil Belajar Matematika Siswa. Jurnal Sainsmat, 7(1), 13-24. https://doi.org/10.31539/judika.v2i1.701.

Fitriana, M., \& Ismah. (2016). Pengaruh Model Pembelajaran Auditory Intellectually Repetition terhadap Hasil Belajar Matematika Siswa Ditinjau Dari Kedisiplinan Siswa. Jurnal Pendidikan Matematika Dan Matematika, 2(1). https: //doi.org/10.24853/fbc.2.1.59-68.

Gusrita, T. (2021). Penerapan Model Pembelajaran Berbasis Masalah untuk Meningkatkan Keterampilan Menulis Teks Eksposisi Siswa MAN 1 Sarolangun. Jurnal Pendidikan Guru, 2(1). https://doi.org/10.47783/jurpendigu.v2i1.192.

Hodiyanto, H. (2017). Pengaruh Model Pembelajaran Problem Solving terhadap Kemampuan Komunikasi Matematis Ditinjau dari Gender. Jurnal Riset Pendidikan Matematika, 4(2), 219. https: //doi.org/10.21831/jrpm.v4i2.15770.

Linuwih, S., \& Sukwati, N. O. E. (2014). Efektivitas Model Pembelajaran Auditory Intellectually Repetition (AIR) terhadap Pemahaman Siswa pada Konsep Energi Dalam. Jurnal Pendidikan Fisika Indonesia, 10(2), 158-162. https://doi.org/10.15294/jpfi.v10i2.3352.

Naitili, C. A., Suardana, I. M., \& Ramli, M. (2019). Penerapan Metode Struktural Analitik Sintetik untuk Meningkatkan Keterampilan Menulis Permulaan Siswa Sekolah Dasar. Jurnal Pendidikan: Teori, Penelitian Dan Pengembangan, 4(5), 660-667. https: //doi.org/10.17977/jptpp.v4i5.12463.

Natalita, R. K., Situngkir, N., \& Rabbani, S. (2019). Meningkatkan Keterampilan Menulis Tegak Bersambung dengan Menggunakan Metode Drill pada Siswa Kelas 1 SD. Journal of Elementary Education, 02(January), 18-25. https://journal.ikipsiliwangi.ac.id/index.php/collase/article/download/3084/804.

Puspitasari, R. P. (2012). Hubungan Konsep Diri dan Kepercayaan Diri dengan Kemampuan Komunikasi Interpersonal pada Remaja Putus Sekolah. Psikologi: Teori \& Terapan, 3(1), 58-66. https://doi.org/10.26740/jptt.v3n1.p58-66.

Putri, F. W., Hartati, T., \& Mulyasari, E. (2019). Penerapan Metode Drill untuk Meningkatkan Keterampilan Menulis Permulaan Siswa Kelas II SD. Jurnal Pendidikan Guru Sekolah Dasar, 4(3), 155-166. https://doi.org/10.17509/jpgsd.v4i3.22916.

S, K. F., Harsiati, T., \& Hasanah, M. (2016). Pengembangan Instrumen Asesmen Autentik Keterampilan Menulis Teks Cerpen dan Teks Fabel untuk Siswa SMP/MTS Yang Mengimplementasikan Kurikulum 2013. Jurnal Pendidikan: Teori, Penelitian Dan Pengembangan, 1(3), 421 - 427. https://doi.org/10.17977/jp.v1i3.6168.

Sarniah, S., Anwar, C., \& Putra, R. W. Y. (2019). Pengaruh Model Pembelajaran Auditory Intellectually Repetition terhadap Kemampuan Pemahaman Konsep Matematis. Journal of Medives : Journal Of Mathematics Education IKIP Veteran Semarang, 3(1), 87-96. https: //doi.org/10.31331/medivesveteran.v3i1.709.

Wahyuni, S., Subiyantoro, S., \& Fadhilah, S. S. (2018). Assisted Learning and Auditory Intellectual PRepetition for Pupil's Mastery in Undha Usuk. Jurnal Kependidikan: Penelitian Inovasi Pembelajaran, 2(1), 13 - 25. https://doi.org/10.21831/jk.v2i1.17987.

Widyaningrum, R. (2019). Upaya Meningkatkan Kemampuan Menulis Tegak Bersambung Melalui Contoh di Buku Halus dan Drill pada Peserta Didik Kelas 1 SDN Jajartunggal III Surabaya. Pendidikan Dasar, 1(1), 34-43. https://doi.org/10.30742/tpd.v1i01.722.

Yarmi, G. (2017). Pembelajaran Menulis di Sekolah Dasar. Perspektif Ilmu Pendidikan, 31(1), 1. 
https://doi.org/10.21009/pip.311.1. 